\title{
Levosalbutamol versus Salbutamol for Treatment of Acute Exacerbation of Asthma in Bangladesh Children
}

\author{
Atiar Rahman ${ }^{1 *}$, Selina khanum ${ }^{1}$ and Simona Turcu ${ }^{2}$ \\ ${ }^{1}$ Department of Pediatrics, Bangabandhu Sheikh Mujib Medical University, Bangladesh \\ ${ }^{2}$ Evelina Children Hospital, London, UK
}

\begin{abstract}
Introduction: Salbutamol is an effective treatment of acute exacerbation asthma but its use is associated with undesirable side effects like tachycardia and hypokalemia. Published studies have showed that levosalbutamol improves pulmonary function more than racemic salbutamol without the known salbutamol side effects.

Objective: To compare the efficacy and tolerability of Levosalbutamol and Salbutamol for the treatment of acute exacerbation of asthma in Bangladesh children aged 8 to 15 years.

Methods: A randomized double blind clinical study included 60 known asthmatic children aged between 8 and 15 years, who attended the emergency department for an acute exacerbation. The studied medicines were salbutamol $2.5 \mathrm{mg}$ and levosalbutamol $0.63 \mathrm{mg}$. The total drug volume was $2.5 \mathrm{ml}$ which was nebulized over a period of 8-10 minutes. Forced expiratory volume in $1^{\text {st }}$ second was measured using Manual Promoter. Spirometry was performed 3 times and the best of the three values was recorded. The following clinical parameters were recorded initially and after giving 3 nebulizations at 20 minutes interval in the $1^{\text {st }}$ hour of presentation: respiratory rate (RR), heart rate $(\mathrm{HR})$, oxygen saturation in room air $\mathrm{SPO}_{2}, \mathrm{FEV}_{1}$ (forced expiratory volume in $1^{\text {st }}$ second), asthma score and serum potassium level.
\end{abstract}

Results: In the levosalbutamol group there was significant increment in $\mathrm{FEV}_{1}$ and $\mathrm{SpO}_{2}(\mathrm{p}<0.05)$ with decreased tachypnea and asthma score while no significant difference was found in the pre and post treatment $\mathrm{HR}$ and serum $\mathrm{K}^{+}$levels. In the Salbutamol group although there was clinical improvement in terms of $\mathrm{FEV}_{1}, \mathrm{SpO}_{2}$ and asthma score, there was significant tachycardia and decrease in $\mathrm{K}^{+}$levels.

Conclusion: Levosalbutamol has similar therapeutic effects with salbutamol in acute exacerbation of asthma but has no side effects such as tachycardia and hypokalemia.

\section{Keywords: Levosalbutamol; Salbutamol; Acute asthma}

\section{Introduction}

Salbutamol, the most commonly used bronchodilator, is a chiral drug with $\mathrm{R}$ and $\mathrm{S}$ Isomers. The commonly used formulation is a racemic mixture that contains equal amount of both $\mathrm{R}$ and $\mathrm{S}$ isomer [1-3]. $\beta_{2}$-agonist Racemic Salbutamol has been the mainstay of treatment for bronchial smooth muscle contraction since 1982 [4]. $\beta 2$-agonist are Racemic mixture that are composed of a 50:50 ratio of (R) and (S) isomers. The R isomer (referred to as levosalbutamol) is the therapeutically active bronchodilator by increasing intracellular calcium in airway smooth muscle cell in vitro which promotes smooth muscle contraction opposing bronchodilation $[5,6]$. Current evidence indicates that the $\mathrm{S}$ isomer is devoid of any bronchodilator activity [7]. Also, levosalbutamol (LEV) the active component of racemic salbutamol (RAC) when administered as the single isomer avoids all of the potential adverse effect of $(S)$ isomer.

Studies have shown that in asthmatic patients, treatment with levosalbutamol decreased hypersensitivity to methacoline to a greater degree and with longer duration of action than does treatment with racemic salbutamol [8-10]. In studies of outpatient asthma patients who were treated with levosalbutamol they experienced a significantly greater increase in $\mathrm{FEV}_{1}$, a longer duration of action and fewer side effects [11-13]. In the emergency department studies showed levosalbutamol improved pulmonary function significantly more than racemic salbutamol and significantly decreased the number of hospitalizations compared to racemic salbutamol [14]. Though salbutamol is an effective treatment of acute exacerbation, its use is associated with undesirable side effects like tachycardia and hypokalemia [15]. Search for a more effective drug with fewer side effects is still on. The purpose of the present study is to evaluate the impact of levosalbutamol on clinical effectiveness and assess the patient outcome. Formulation of salbutamol containing only R-isomer (levosalbutamol) has been available on the national and international market for the last few years. So far to our knowledge, efficacy and tolerability of levosalbutamol have not been compared with racemic salbutamol in acute exacerabation asthma in children.

\section{Objective}

To compare the efficacy and tolerability of Levosalbutamol and Salbutamol for the treatment acute exacerbation of asthma in children aged 8 to 15 years.

\section{Materials and Methods}

This was a randomized double blind clinical study that included 60 known asthmatic children of both sexes aged 8 to 15 years who

*Corresponding author: Atiar Rahman, Department of Pediatrics, Bangabandhu Sheikh Mujib Medical University, Dhaka, Bangladesh; E-mail: atiar777@yahoo.com

Received September 24, 2012; Accepted November 20, 2012; Published November 24, 2012

Citation: Rahman A, khanum S, Turcu S (2012) Levosalbutamol versus Salbutamol for Treatment of Acute Exacerbation of Asthma in Bangladesh Children. J Allergy Ther 3:123. doi:10.4172/2155-6121.1000123

Copyright: (c) 2012 Rahman A, et al. This is an open-access article distributed under the terms of the Creative Commons Attribution License, which permits unrestricted use, distribution, and reproduction in any medium, provided the original author and source are credited. 
attended the emergency department for acute asthma exacerbation. The studied medicines were salbutamol $2.5 \mathrm{mg}$ and levosalbutamol $0.63 \mathrm{mg}$ concealed in a numbered envelope. All the eligible patients were randomly assigned. The total drug volume was $2.5 \mathrm{ml}$ which was nebulized over a period of 8-10 minutes. Severity of asthma was assessed using the asthma score illustrated in table 1 [16].

Children were treated in ED for 1 hour. No steroids were given in $\mathrm{ED}$ and further drug treatment for admitted children followed the local asthma protocol.

The following parameters were recorded initially and after giving 3 nebulizations at 20 minutes interval in the $1^{\text {st }}$ hour of presentation: respiratory rate $(\mathrm{RR})$, heart rate (HR), oxygen saturation in room air $\mathrm{SPO}_{2}$, asthma score and serum $\mathrm{K}^{+}$level. Forced expiratory volume in $1^{\text {st }}$ second $\left(\mathrm{FEV}_{1}\right)$ was measured using Manual Spirometer. Children had spirometry 3 times and best of the three values was recorded.

\section{Study design}

The study was conducted according to the International Conference on Harmonization (ICH) Guideline for Good Clinical Practice (CGP) and the clinical treatment protocol was approved by the ethical Committee of the University and departmental review board. A randomized double blind hospital based comparative study was used to asses the effects of the two drugs on the above mentioned parameters. Randomization was performed using a random number sequence, a computer and STATA 8.0 software. Two resident doctors responsible for the study prepared the randomization series the assignment was then performed using opaque envelop, A sequence number was assigned to each of these sealed envelope, thus blinding was ensured.

\section{Location and period of study}

The study was carried out in the asthma center (ED) of Pediatric Department, Bangabandhu Sheikh Mujib Medical University (BSMMU), from September 2009 to August 2011.

\section{Study population}

Group I- Levosalbutamol group $\mathrm{n}=30$

Group II- Salbutamol group $\mathrm{n}=30$

\begin{tabular}{|l|l|l|l|}
\hline \multicolumn{5}{|c|}{ Asthma Severity Assessement Asthma Score } \\
\hline & 1 point & 2 point & 3 point \\
\hline Resp. rate & & & \\
\hline 2-3 yrs & $\leq 34$ & $35-39$ & $\geq 40$ \\
\hline $4-5$ yrs & $\leq 30$ & $31-35$ & $\geq 36$ \\
\hline $6-12$ yrs & $\leq 26$ & $27-30$ & $\geq 31$ \\
\hline$>12$ yrs & $\leq 23$ & $24-27$ & $\geq 28$ \\
\hline $\begin{array}{l}\text { O2 saturation in } \\
\text { (room air) }\end{array}$ & $>95 \%$ & $90-95 \%$ & $\leq 90 \%$ \\
\hline Auscultation & $\begin{array}{l}\text { No to mild } \\
\text { end-expiratory } \\
\text { wheezing }\end{array}$ & $\begin{array}{l}\text { Expiratory } \\
\text { Wheezing }\end{array}$ & $\begin{array}{l}\text { Ins+Exp wheezing or } \\
\text { Diminished BS }\end{array}$ \\
\hline Retraction & $\begin{array}{l}\text { None or } \\
\text { Intercostal }\end{array}$ & $\begin{array}{l}\text { Intercostal+ } \\
\text { substernal }\end{array}$ & $\begin{array}{l}\text { Intercostal, Subster- } \\
\text { nal+ Supraclavicular }\end{array}$ \\
\hline Dyspnoea & $\begin{array}{l}\text { Speaks in sen- } \\
\text { tences or coos } \\
\text { and babbles }\end{array}$ & $\begin{array}{l}\text { Speaks in partial } \\
\text { sentences, or } \\
\text { utter short cries }\end{array}$ & $\begin{array}{l}\text { Speaks in single } \\
\text { words or short } \\
\text { phrases, or grunt. }\end{array}$ \\
\hline Severity Assessment & Mild & rModeate & Severe \\
\hline Asthma Score & $5-7$ & $8-11$ & $12-15$ \\
\hline \% FEV & $<80 \%$ & $50-65 \%$ & $<50 \%$ \\
\hline & Table 1: Scoring & sevity of asthma. \\
\hline
\end{tabular}

Table 1: Scoring severity of asthma

\begin{tabular}{|l|l|l|l|}
\hline & Group 1 (LEV) & Group 2 (RAC) & P value \\
\hline $\begin{array}{l}\text { Age (years) } \\
\text { Sex } \\
\text { Boys }\end{array}$ & $10.57 \pm 3.60$ & $10.77 \pm 4.05$ & $p>.05$ \\
Girls & 17 & 16 & $p>.05$ \\
\hline ED visits (past 12 mths) & 13 & 14 & \\
0 & & & \\
$\geq 1$ & 11 & 13 & $p>.05$ \\
\hline Hospitalization (past 12 mths) & 19 & 17 & \\
0 & & & \\
$\geq 1$ & 23 & 24 & $p>.05$ \\
\hline $\begin{array}{l}\text { Duration of illness (years } \\
\text { mean } \pm \text { SD) }\end{array}$ & $4.15 \pm 2.17$ & $3.95 \pm 2.54$ & $p>.05$ \\
\hline
\end{tabular}

Table 2: Characteristic of patients in the two groups.

Inclusion criteria: Asthma patient 8-15 years presenting with acute exacerbation.

Exclusion criteria: Age below 8 years and above 15 years, children already on preventive therapy (inhaled steroids or long acting bronchodilator LABA), first episode of wheezing, congenital heart diseases, cystic fibrosis and other chronic lung diseases were excluded from the study.

\section{Data collection and evaluation}

Parents or care takers were given a detailed briefing about the purpose of the study. Informed consent forms were signed by the subject or the subjects legally authorized representative before his/ her participation in the study. Before and after giving levosalbutamol or salbutamol baseline clinical parameter RR, $\mathrm{HR}, \mathrm{SPO}_{2}$, asthma score and serum $\mathrm{K}^{+}$level were recorded and compared on a designed proforma. All the values were expressed as mean \pm SD for pre and post treatment effects. Comparative analysis of baseline parameters of two groups and within the groups and percentage of improvement between these two groups before and after treatment was done using unpaired " $t$ " test. All the statistical analysis was done by using SPSS package 16 version.

\section{Result}

Baseline characteristic age, sex, diagnosis, duration of asthma were comparable between the two groups ( $\mathrm{p}$ value $>0.05$ ) (Table 2). None of the patients were receiving preventive therapy like steroids or LABA before presenting to ED. Patients were either lost to preventive therapy or never initiated on preventive therapy, none was given steroids during their 1 hour stay at ED.

The following parameters were recorded initially and after giving 3 nebulizations at 20 minutes interval in the $1^{\text {st }}$ hour of presentationrespiratory rate $(\mathrm{RR})$, heart rate (HR), oxygen saturation in room air $\mathrm{SPO}_{2}, \mathrm{FEV}_{1}$ (forced expiratory volume in $1^{\text {st }}$ second), asthma score and serum $\mathrm{K}^{+}$level. In levosalbutamol group, there was significant increment in $\mathrm{FEV}_{1}$ and $\mathrm{SPO}_{2}(\mathrm{p}<0.05)$ with decrease tacypnea and asthma score while no significant difference was found in pre and post treatment $\mathrm{HR}$ and serum $\mathrm{K}^{+}$levels. In the Salbutamol group although there was clinical improvement in terms of $\mathrm{FEV}_{1}, \mathrm{SPO}_{2}$ and asthma score, it resulted in significant tachycardia and decrease in $\mathrm{K}^{+}$levels (Tables 3 and 4 ).

\section{Discussion}

It has been established that regular and excessive use of racemic salbutamol (RAC) induces paradoxical reaction in some subject 


\begin{tabular}{|l|l|l|l|}
\hline Parameters & Pre-treatment & Post-treatment & P-value \\
\hline $\mathrm{RR}$ & $30.53 \pm 5.12$ & $26.63 \pm 0.60$ & $<0.05$ \\
\hline $\mathrm{HR}$ & $110 \pm 18.20$ & $109.43 \pm 13.25$ & $>0.05$ \\
\hline $\mathrm{SpO}_{2}$ & $95.57 \pm 14.81$ & $98.43 \pm 11.12$ & $<0.05$ \\
\hline $\mathrm{FEV}_{1}$ & $50.50 \pm 10.12$ & $\begin{array}{l}69.80 \pm 12.50 \\
19 \%\end{array}$ & $<0.05$ \\
\hline Serum $\mathrm{K}^{+}$ & $4.78 \pm 0.80$ & $4.53 \pm 0.59$ & $>0.05$ \\
\hline Asthma score & $7.80 \pm 1.25$ & $5.6 \pm 0.79$ & $<0.05$ \\
\hline
\end{tabular}

Table 3: Pre and Post-treatment observation of levosalbutamol group (LEV).

\begin{tabular}{|l|l|l|l|}
\hline Parameters & Pre-treatment & Post-treatment & P-value \\
\hline $\mathrm{RR}$ & $30.7 \pm 4.15$ & $27.37 \pm 3.50$ & $<0.05$ \\
\hline $\mathrm{HR}$ & $109.52 \pm 18.56$ & $124.52 \pm 16.02$ & $<0.05$ \\
\hline $\mathrm{SPO}_{2}$ & $96.78 \pm 13.52$ & $98.12 \pm 7.20$ & $<0.05$ \\
\hline $\mathrm{FEV}_{1}$ & $51.12 \pm 10.90$ & $\begin{array}{l}68.99 \pm 13.12 \\
18 \%\end{array}$ & $<0.05$ \\
\hline Serum K & & $3.65 \pm 0.51$ & $>0.05$ \\
\hline Asthma score & $8.65 \pm 0.70$ & $6.26 \pm 0.71$ & $<0.05$ \\
\hline
\end{tabular}

Table 4: Pre- and post-treatment observation of salbutamol (RAC).

with asthma [8]. This has led to development of safer and at least equally therapeutically active agents of the available $\beta_{2}$-agonists. Levosalbutamol (LEV), the active component of racemic salbutamol avoids the potential adverse effect of (S) isomer when administered as the single isomer. "Levosalbutamol" was approved by Food and Drug Administration (FDA) in 1999 as a purified single isomer for clinical use in asthma patients.

Levosalbutamol (LEV) has approximately 2 fold greater affinity than the racemic salbutamol for the $\beta$ adrenergic receptor and approximately 100 fold greater binding affinity than S-salbutamol. LEV elevates intracellular concentration of cylic AMP (cAMP) by activating adenyl cylase. In the airways, increased concentration of cAMP relaxes bronchial smooth muscle by reducing intracellular calcium and prevents contraction of hyperresponsive airways. Increased concentration of cAMP also inhibit the release of inflammatory mediators from mast cells and eosinophil $[2,13,14,16]$.

Milgrom et al. previously compared LEV to RAC in pediatric population with chronic stable asthma showing that LEV $(0.63 \mathrm{mg})$ produces greater change in $\mathrm{FEV}_{1}$ immediately post nebulization (18\%) when compared to RAC $2.5 \mathrm{mg}(15.6 \%)$ [10]. Our study in acute exacerbation showed the 2 drugs made $19 \%$ and $18 \%$ increase respectively indicating similar therapeutic effects.

Study assessing the efficacy of LEV in acute exacerbation of asthma have been carried in adults $[12,17]$ but only one in children done by Punj in India among children aged 5-18 years presenting in the ED with acute exacerbation of asthma. The patients had initial mean PEFR $<80 \%$ of predicted and nebulized LEV $(0.63 \mathrm{mg})$ at presentation. Results showed efficacy in terms of improvement in $\mathrm{SpO}_{2}, \mathrm{PEFR}$ and asthma score $(\mathrm{P}<0.01)$ and better tolerability, less tachycardia and less hypokalemia compared to RAC $(\mathrm{P}<0.01)$ [1]. Our study result shows that both have same therapeutic effect with less significantly less tachycardia and hyokalemia in the LEV group $(\mathrm{P}<0.05)$.

Another study was conducted in children aged 1-5 years with reactive airway diseases that compared LEV with RAC and assessed hospitalization as outcome measure showing shorter hospitalization with LEV [2,14]. Although this outcome measure is not same as in the present study it points towards usefulness of LEV similar to the present results. In this study there was no demonstration of reduction of side effects like tremor and tachycardia but then they used a higher dose of LEV (1.25 mg) while our patients had a lower dose of LEV (0.63 mg).

Ralston et al. compared LEV with a combination of salbutamol and ipratropium bromide in children between 6-18 years presenting with acute asthma and reported that LEV was associated with less tachycardia but showed no other advantage of associating RAC with ipratropium bromide $[2,18]$. Our study underlines the fact that while having similar effects with RAC alone, LEV does not cause either tachycardia or hypokalemia $[2,18]$.

\section{Conclusion}

Levosalbutamol has equally good effect with salbutamol in improving $\mathrm{FEV}_{1}, \mathrm{SpO}_{2}$ and asthma score in acute exacerbation of asthma in children but better tolerability in terms of tachycardia and hypokalemia compared to salbutamol.

\section{References}

1. Punj A, Prakash A, Bhasin A (2009) Levosalbutamol vs racemic salbutamol in the treatment of acute exacerbation of asthma. Indian J Pediatr 76: 1131-1135.

2. Penn RB, Frielle T, McCullough JR, Aberg G, Benovic JL (1996) Comparison of $\mathrm{R}$-, S- and RS-albuterol interaction with human beta 1- and beta 2-adrenergic recepters. Clin Rev Allergy Immunol 14: 37-45.

3. Page CP, Morley J (1999) Contrasting properties of albuterol stereoisomers. J Allergy Clin Immuno 104: S31-S41.

4. National Asthma Education and Prevention Program (1997) Expert panel report 2: guidelines for the diagnosis and management of asthma. US Department of Health and Human Services, Public health service, National Institute of Health Bethesda.

5. Mitra S, Ugur M, Ugur O, Goodman HM, McCullough JR, et al. (1998) (S)Albuterol increases intracellular free calcium by muscarinic receptor activation and a phospholipase C-dependent mechanism in airway smooth muscle. Mol Pharmacol 53: 347-354.

6. Yamaguchi H, McCullough JR (1996) S-albuterol exacerbates calcium response to carbachol in airway smooth muscle cells. Clin Rev Allergy Immunol 14: $47-55$

7. Perrin-Fayolle M (1995) Salbutamol in the treatment of asthma. Lancet 346 1101.

8. Van Essen-Zandvliet EE, Hughes MD, Waalkens HJ, Duiverman EJ, Pocock SJ, et al. (1992) Effect of 22 months of treatment with inhaled corticosteroids and/ or beta-2-antagonists on lung function, airway responsiveness, and symptom in children with asthma. The Dutch Chronic Non-specific Lung Disease Study Group. Am Rev Respir Dis 146: 547-554.

9. Nelson HS, Bensch G, Pleskow WW, DiSantostefano R, DeGraw S, et al. (1998) Improved bronchodilation with Levalbuterol compared with racemic albuterol in patients with asthma. J Allergy Clin Immunol 102: 943-952.

10. Milgrom H, Skoner DP, Bensch G, Kim KT, Claus R, et al. (2001) Low-dose Levalbuterol in children with asthma: safety and efficacy compared with placebo and racemic albuterol. J Allergy Clin Immunol 108: 938-945.

11. Gawchik SM, Saccer CL, Noonan M, Reasner DS, DeGraw SS (1999) The safety and efficacy of nebulized Levalbutarol compared with racemic albuterol and placebo in the treatment of asthma in pediatric patients. J Allergy Clin Immunol 103: 615-621.

12. Nowak RM, Emerman CL, Schaefer K, Disantostefano RL, Vaickus L, et al. (2004) Levalbuterol compared to racemic albuterol in the treatment of acute asthma : result of a pilot study. Am J Emerg Med 22: 29-36

13. Canning B (2002) Pharmacological properties of S-salbutamol in human airway smooth muscle preparation. Am J Resp Crit Care Med 165: A770.

14. Carl JC, Myers TR, Kirchner HL, Kercsmar CM (2003) Comparison of racemic albutarol and Levalbuterol for treatment of acute asthma. J Pediatr 143: 731 736. 
Citation: Rahman A, khanum S, Turcu S (2012) Levosalbutamol versus Salbutamol for Treatment of Acute Exacerbation of Asthma in Bangladesh Children. J Allergy Ther 3:123. doi:10.4172/2155-6121.1000123

Page 4 of 4

15. Skoner DP, Greos LS, Kim KT, Roach JM, Parsey M, et al. (2005) Evaluation of the safety and efficacy of Levalbuterol in 2-5-year-old patients with asthma. Pediatr Pulmonol 40: 477-486.

16. Qureshi F, Pestian J, Davis P, Zaritsky A (1998) Effect of nebullized ipratropium on the hospitalization rates of children with asthma. N Engl J Med 339: 10301035.
17. Haider D (2001) Levalbuterol (LEV) affords superior health and cost benefit over racemic albuterol in the emergency department. Resp Care 46: 1081.

18. Ralston ME, Euwema MS, Knecht KR, Ziolkowski TJ, Coakley TA, et al. (2005) Comparison of levalbuterol and racemic albuterol combined with ipratropium bromide in acute pediatric asthma: a randomized controlled trial. J Emerg Med 29: $29-35$ 